УДК 616.316-006.55-018-076

DOI 10.11603/2311-9624.2020.1.11219

\author{
CV. O. Malanchuk ${ }^{1, E, F}$, I. S. Brodetskyi ${ }^{1, A, B, C, D}$, M. S. Krotevych ${ }^{2, E, F}$ \\ O. Bohomolets National Medical University, Kyiv ${ }^{1}$ \\ National Cancer Institute, Kyiv ${ }^{2}$ \\ e-mail: i2g3o4@bigmir.net
}

Внесок кожного з авторів у виконання досліджень, які публікуються у статті. A, B,C,D,E, F, де A - концепція та дизайн дослідження; B - збір даних; C - аналіз та інтерпретація даних; D - написання статті; E - редагування статті; F - остаточне затвердження статті (A - research concept and design; $\mathrm{B}$ - collection and/or assembly of data; $\mathrm{C}$ - data analysis and interpretation; D - writing the article; E-critical revision of the article; F - final approval of the article)

\title{
Application of immunohistochemical markers in diagnostics of various histological types of pleomorphic adenomas of the salivary glands
}

INFORMATION

Received/Надійшла до редакції: 12.11.2019 p.

Key words: salivary gland tumors; immunohistochemistry; human papillomavirus; histological types of pleomorphic adenomas.

\section{ABSTRACT}

Summary. The morphological verification of tumors as a diagnostic method has been the basis for establishing the final diagnosis for a long time. According to various data, the accuracy of the diagnosis ranges from $80-85 \%$, depending on the type of tumor (benign or malignant) and its differentiation. With the introduction of immunohistochemical studies for the final diagnosis of tumors, the percentage of verified tumors has increased significantly.

The aim of the study - determination of peculiarities of pathogenesis of various histological types of pleomorphic adenomas of the salivary glands applying the methods of immunohistochemical diagnostics.

Materials and Methods. The study was conducted based on the excisional biopsies of the pleomorphic adenomas of the salivary glands in 28 patients. The immunohistochemistry analyses were performed with Monoclonal Mouse Anti-Epstein Barr Virus, Polyclonal Rabbit Antibody p16, Monoclonal Rabbit Anti-Human Estrogen Receptor (ER), and the Mouse Anti-Human Progesterone Receptor (PR), PLAG1 (pleomorphic adenoma gene 1) Monoclonal Antibody.

Results and Discussion. The results of the conducted study of the own surgical material show that the structure of histological types of pleomorphic adenomas of the salivary glands is as follows: mesenchymal 15 (53.57 \%), epithelial-mesenchymal - 10 (35.47\%), epithelial - 3 (10.71\%). The mesenchymal and epithelial-mesenchymal types of histological structure of pleomorphic adenomas of the salivary glands are characterized by the similar immunohistochemical peculiarities (Plag1 - positive response in tumor cells of both histological types in $100 \%$ of cases; HPV $16-73.33 \%$ and $80.0 \%$ respectively and EBV $33.33 \%$ and $30.0 \%$ respectively). The epithelial type of structure of the pleomorphic adenomas of the salivary glands is characterized by slightly different immunohistochemical pattern: Plag1 - positive response in tumor cells in $66.66 \%$ of cases; HPV 16 - also in $66.66 \%$ of cases. The mesenchymal and epithelial-mesenchymal types of histological structure of pleomorphic adenomas of the salivary glands are characterized by more frequent invasion of HPV 16 and EBV.

Conclusions. The mesenchymal and epithelial-mesenchymal types of histological structure of pleomorphic adenomas of the salivary glands are characterized by more frequent invasion of HPV 16 and EBV. 
Introduction. The morphological verification of tumors as a diagnostic method has been the basis for establishing the final diagnosis for a long time. According to various data, the accuracy of the diagnosis ranges from $80-85 \%$, depending on the type of tumor (benign or malignant) and its differentiation [1]. There are many morphological signs of different types of tumors. However, some tumors have a clear morphology, while others are characterized by a fairly pronounced morphological polymorphism (histological diversity of the structure) [2].

Among the latter, salivary gland tumors are a typical example. According to numerous sources, their frequency ranges from 1 to $5 \%$ of all head and neck cancers. The most common tumor of the salivary glands is pleomorphic adenoma, which occurs in $61-90 \%$ of cases and most often affects the parotid salivary gland. The peculiarity of its clinical progression is a significant percentage of relapse (from 1 to $50 \%$, according to various authors), which is associated with several factors: a predominance of the myxoid component in the tumor structure, a difference in the thickness of the capsule, together with the ability of the tumor to attach to the capsule, individual tumor nodes being "immured" within the capsule, a "viability" of the tumor cells, and multifocal growth [3].

The presence of various histological types of pleomorphic adenomas of the salivary glands has been listed by various authors as from 2 to 4 types of PA. Nowadays in pathohistology, all pleomorphic adenomas (PA) are divided into two types - mesenchymal and epithelial. This is the first classification and most scientists use it. However, some other scientists write that there are 3 types of pleomorphic adenomas (mesenchymal, epithelial, and combined). This is the second classification. There is a further classification and an opiion of scientists where they write about 4 types of pleomorphic adenomas (PA) - mesenchymal, epithelial, combined, and myoepithelial - this is the third classification. What does it mean by myoepithelial? It means that there is a situation where the myoepithelial components dominate more than $50 \%$ of the sample tissues. Four types of PA are the maximum known at this time. This third classification has existed for 14 years and it was developed in 2005 by Huskova O.N.

In this current study, the researchers have focused on the three classifications of PA, namely: 1) mesenchymal and epithelial; 2) mesenchymal, epithelial and combined; and 3) mesenchymal, epithelial, combined, and myoepithelial. These classifications of PA may complicate the morphological verifications and the differentiations of the tumor, which will then require the additional use of modern methods for a histological diagnosis confirmation [4].

With the introduction of immunohistochemical studies for the final diagnosis of tumors, the percentage of verified tumors has increased significantly. There is now an opportunity to determine not only the tumor type, but also its subtype and its differentiation, and then plan the chemotherapy for the malignant neoplasms [5]. The use of an immunohistochemical study for pleomorphic adenomas has revealed an expression among the different groups of viruses (HPV type 16 and EBV), ER (estrogen), and the PR (progesterone) receptors, as well as the diagnostic marker PLAG1 $[6,7,8]$. Thus, the use of these markers will identify possible etiological influences (factors) in the development of pleomorphic adenoma of the salivary glands, not only as a whole, but also depending on their type of structure (mesenchymal, epithelial, combined, myoepithelial) and increase the percentage of verification of this type of tumor.

Despite the large number of scientific works devoted to the study of various aspects of the pleomorphic adenomas, in particular, their histological characteristics and their immunohistochemical markers, there are no papers related to the study of the peculiarities of pathogenesis of various histological types of pleomorphic adenomas of the salivary glands. Thus, the aim of our study is to determine the peculiarities of pathogenesis of various histological types of pleomorphic adenomas of the salivary glands applying the methods of immunohistochemical diagnostics.

Materials and Methods. The histological typing of the salivary gland tumors was performed using routine staining with hematoxylin and eosin, and immunohistochemistry. The study was conducted based on the excisional biopsies of the pleomorphic adenomas of the salivary glands in 28 patients. For the study, a 10x10 tumor of up to 4 $\mathrm{mm}$ in thickness was collected from the removed parotid and the submandibular salivary glands. The cut tumor pieces were inserted into cassettes, then placed into the cassette holder, which was moved to a fixation container with $10 \%$ formalin buffered with pH 7.4 for 16 hours. The material was condensed in paraffin using a Histos-5 histoprocessor (Milestone, Italy), according to the program for surgical material $-4 \mathrm{~mm}$. After completing the paraffin-condensing program, the cassettes were removed from the paraffin block of 
the histoprocessor and moved to the filling station of the HESTION TEC-2800 Embedding Center, where they were filled with molten paraffin. This was followed by freezing in the refrigerator module of the HESTION TEC-2800 Cryo Console. From the obtained paraffin blocks, histological sections were made of 5 microns thick using a Microm HM 325 (Thermo Scientific, Germany) microtome. The sections were stained with hematoxylin and eosin for the histopathological examinations of the tumor, the morphometry, and for the calculations of the volume of viable tumor tissue.

The immunohistochemistry was performed with PLAG1 Monoclonal Antibody (M02) clone 3B7, China; Monoclonal Mouse Anti-Epstein Barr Virus LMP Clones CS. 1-4 (Dako IS 753, Denmark); Polyclonal Rabbit Antibody p16 (CDKN2A) (Thermo Scientific PAL. 16662); Monoclonal Rabbit Anti-Human Estrogen Receptor a Clone SPI (Dako IS 151, Denmark); Mouse Anti-Human Progesterone Receptor Clone PgR 636 (Dako IR068, Denmark); with the use of an EnVision TM FLEX detection system, Dako, Denmark. The antigen masking was carried out in a citrate buffer of pH 6.0 at $95{ }^{\circ} \mathrm{C}$. The obtained histological tissue samples were studied and photographed using an OLYMPUS CX 41 microscope with a Quick PHOTO MICRO 2.3 camera and software under standardized conditions. The tissue samples with a definite positive reactivity were used for the positive control, and for the negative control, the procedure without the use of primary antibodies was performed.

Statystical analysis. The evaluation of intergroup frequency dependence (indicate the groups - mesenchymal, epithelial, combined histological types of pleomorphic adenomas of salivary glands) was performed by means of $\chi^{2}$ test ("chisquared test") [9].

Results and Discussion. In order to calculate the distribution of the patients with a different histological structure of the pleomorphic adenomas, the researchers used the classification as proposed by O. Huskova (2005). Thus, depending on the histological structure, there were 4 types of pleomorphic adenomas, according to this classification: mesenchymal, epithelial, combined (the same number of mesenchymal and epithelial components), and myoepithelial. However, those patients with a myoepithelial type of pleomorphic adenoma were not identified in this current study.

Table 1. Immunohistochemical indices of the mesenchymal type of pleomorphic adenoma of the salivary glands (n $=15,53.57 \%$ )

\begin{tabular}{|c|c|c|}
\hline Mesenchymal type of pleomorphic adenoma & Absolute quantity & $\begin{array}{c}\text { Relative quantity } \\
(\%)\end{array}$ \\
\hline 1.ER & 1 & 6.66 \\
\hline 2.PR & 2 & 13.33 \\
\hline 3.EBV & 5 & 33.33 \\
\hline 4.HPV16 & 11 & 13.33 \\
\hline 5.PLAG1 & 15 & 100 \\
\hline Total number of examined patients with a mesenchymal type of \\
pleomorphic adenoma
\end{tabular}

* When calculating, the researchers took into account that one patient had several positive immunohistochemical indices at once.

The immunohistochemical analyses of the mesenchymal type of pleomorphic adenomas of the salivary glands showed that most patients had positive reactions to HPV type 16 and EBV, being $11(73.33 \%)$ and 5 (33.33 \%) patients, respectively. Positive reactions to ER and PR were expressed in only 2 patients and made up 1 (6.66 \%) and 2 (13.33 $\%)$ patients, respectively. All of the patients had positive reactions to PLAG1 - 15 (100\%) (Fig.1,2).

The immunohistochemical analyses of the combined (mesenchymal and epithelial) type of pleomorphic adenomas of the salivary glands showed that most patients had positive reactions to HPV type 16 and EBV, being 8 (80 \%) and $3(30 \%)$ patients, respectively. Positive reactions to ER and PR were expressed in only 2 patients and they amounted to $1(10 \%)$ and $1(10 \%)$, respectively. All of the patients had positive reactions to PLAG1 - 10 (100 \%) (Fig.3,4).

The immunohistochemical analyses of the epithelial type of pleomorphic adenoma of the salivary glands showed that 2 of the patients had positive reactions to HPV type 16 and PLAG1, 2 (66.66 \%) and 2 (66.66 \%) patients, respectively. 


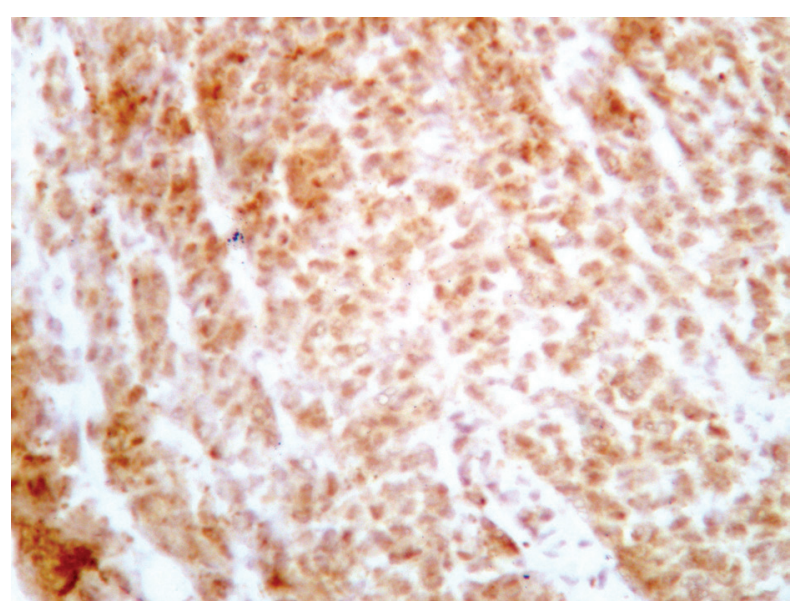

Fig. 1. Photo of a histological tissue sample of pleomorphic adenoma of the parotid salivary gland (mesenchymal histological type) of patient R., 48 years old. Magnification x. 200. Strong positive nuclearcytoplasmic immunohistochemical reaction to HPV type 16.

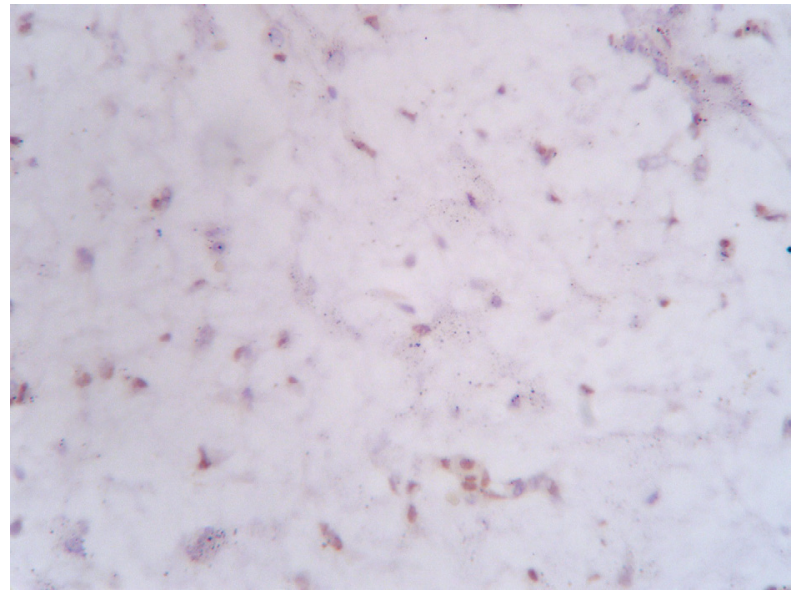

Fig. 2. Photo of a histological tissue sample of pleomorphic adenoma of the parotid salivary gland (mesenchymal histological type) of patient R., 48 years old. Magnification $\times 200$. Weak positive nuclearcytoplasmic immunohistochemical reaction to EBV (indicated by an arrow).

Table 2. Immunohistochemical indices of the combined (mesenchymal and epithelial) type of pleomorphic adenoma of the salivary glands $(n=10,35.71 \%)$.

\begin{tabular}{|c|c|c|}
\hline $\begin{array}{c}\text { Combined (mesenchymal and epithelial) type of pleomorphic } \\
\text { adenoma }\end{array}$ & Absolute quantity & $\begin{array}{c}\text { Relative quantity } \\
\text { (\%) }\end{array}$ \\
\hline ER & 1 & 10 \\
\hline PR & 1 & 10 \\
\hline EBV & 3 & 30 \\
\hline HPV 16 & 8 & 80 \\
\hline PLAG1 & 10 & 100 \\
\hline $\begin{array}{c}\text { Total number of examined patients with the combined } \\
\text { (mesenchymal and epithelial) type of pleomorphic adenoma }\end{array}$ & 10 & 100 \\
\hline
\end{tabular}

* When calculating, the researchers took into account that one patient had several positive immunohistochemical indices at once.

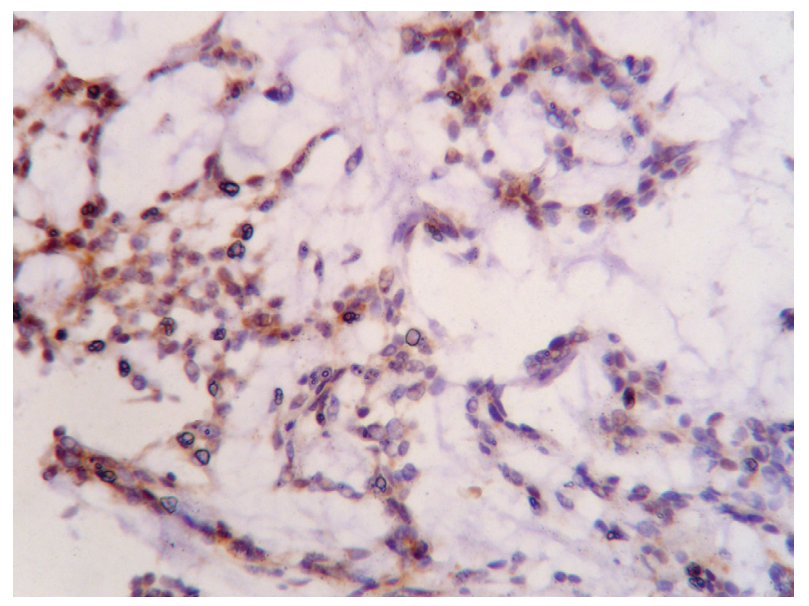

Fig. 3. Photo of a histological tissue sample of pleomorphic adenoma of the parotid salivary gland (mesenchymal and epithelial histological type) of patient P., 23 years old. Magnification $\times 200$. Moderately positive nuclear immunohistochemical reaction to ER (estrogen receptor) (indicated by an arrow).

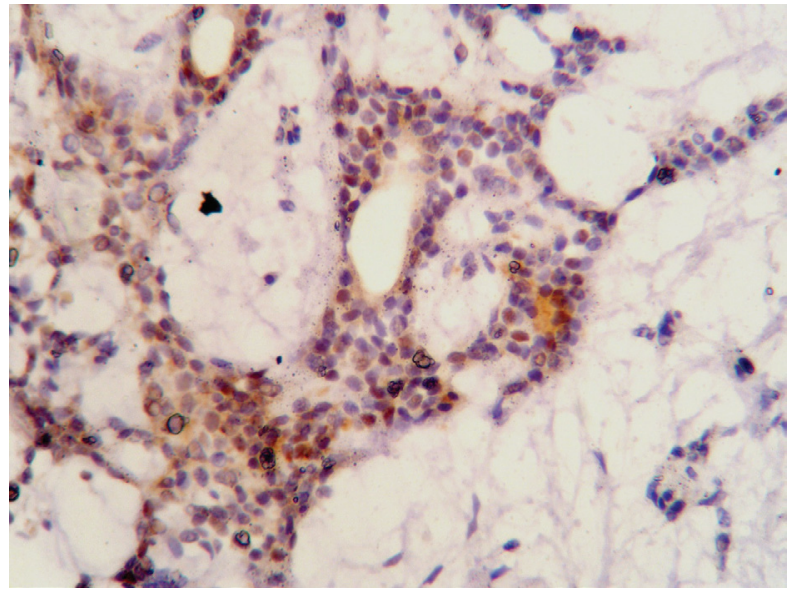

Fig. 4. Photo of a histological tissue sample of pleomorphic adenoma of the parotid salivary gland (mesenchymal and epithelial histological type) of patient P., 23 years old. Magnification $\times 200$. Moderately positive nuclear immunohistochemical reaction to PR (progesterone receptor) (indicated by an arrow).

ISSN 2311-9624. Клінічна стоматологія. 2020. № 1 


\section{Хірургічна стоматологія}

Table 3. Immunohistochemical indices of the epithelial type of pleomorphic adenoma of the salivary glands $(\mathrm{n}=3,10.71 \%)$

\begin{tabular}{|c|c|c|}
\hline Epithelial type of pleomorphic adenoma & Absolute quantity & $\begin{array}{c}\text { Relative quantity } \\
\text { (\%) }\end{array}$ \\
\hline ER & - & - \\
\hline PR & - & - \\
\hline EBV & - & 66.66 \\
\hline HPV 16 & 2 & 66.66 \\
\hline PLAG1 & 2 & 100 \\
\hline
\end{tabular}

* When calculating, the researchers took into account that one patient had several positive immunohistochemical indices at once.

* The indicator was negative in one patient!

The reactions to ER and PR, and to the EpsteinBarr virus, were negative (Fig. 5,6).

Since the statistical significance has not been achieved (between groups - mesenchymal,

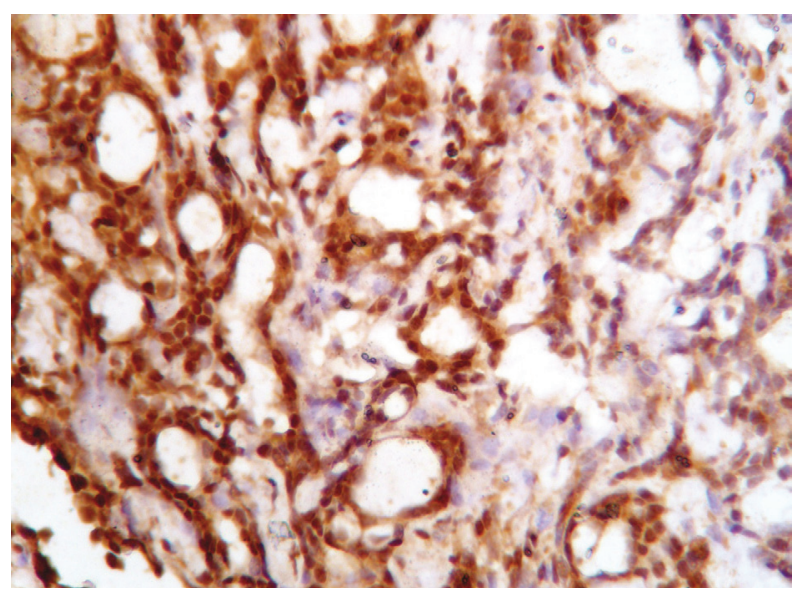

Fig. 5. Photo of a histological tissue sample of pleomorphic adenoma of the parotid salivary gland (epithelial histological type) of patient G., 36 years old. Magnification $\times 200$. Strong positive nuclearcytoplasmic immunohistochemical reaction to HPV16 (indicated by an arrow).

The immunohistochemical analysis of the removed tumor material remains one of the most important methods of final diagnosis for the biopsy material, along with the pathohistological examination [10]. This method is most often used for the verification of malignant neoplasms and for a further selection of the targeted chemotherapy. The importance of immunohistochemistry in the diagnosis of benign tumors is also beyond doubt. The ability for malignancy and the relapse of some of them, like the pleomorphic adenomas of the salivary glands, prompt a search for more epithelial, combined histological types of pleomorphic adenomas of salivary glands), we made a conclusion that there is no dependence between the groups.

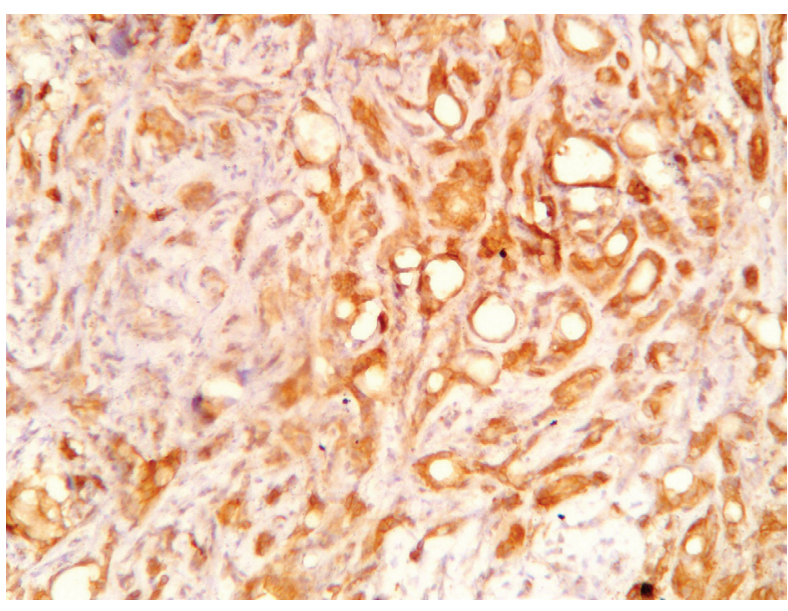

Fig. 6. Photo of a histological tissue sample of pleomorphic adenoma of the parotid salivary gland (epithelial histological type) of patient G., 36 years old. Magnification $\times 200$. Strong positive nuclearcytoplasmic immunohistochemical reaction to PLAG1 (indicated by an arrow).

modern and targeted immunohistochemical tumor markers [11].

It is well-known that chromosomal translocations in control points 8q12, 3p21, and 12q13-15, which correspond to the PLAG1, b-catenin 8, and HMGIC9 genes, are one of the factors for the development of pleomorphic adenoma [12]. PLAG1 is currently the main and most reliable immunohistochemical marker that is used to confirm the diagnosis of pleomorphic adenoma of the salivary glands. 
PLAG1 (pleomorphic adenoma gene 1) is a proto-oncogene, which according to some reports, occurs in $93 \%$ of cases of pleomorphic adenomas, and in $94 \%$ of cases with a relapse of pleomorphic adenoma. It is expressed in the epithelial cells, but it is more frequently found in the myoepithelial cells. It plays a certain role in embryogenesis and fetal development and it reduces its expression during morphosis. In addition to pleomorphic adenomas, the PLAG1 expression has also been described in lipoblastomas, hepatoblastomas, leiomyomas, leiomyosarcomas, and in some cases of acute myeloid leukemia. The PLAG1 protein enhances the expression of several gene growth factors, not only significantly contributing to the tumor genes, but also in suppressing the genes that inhibit cell proliferation. Therefore, PLAG1 may play a double role in tumor formations, and this has been confirmed in various studies of benign tumors and low-differentiated carcinomas [6].

The influence of viral infections on tumor development is already well known. Most of them play a significant role in the etiology of both benign and malignant tumors. Among the most prominent viral agents are human papillomavirus, Epstein-Barr, cytomegalovirus, hepatitis B, hepatitis C, and various types of herpesvirus. Human papillomavirus, cytomegalovirus, and the herpes simplex virus play a significant role in the development of cervical cancer [13]. Human papillomavirus causes the development of various types of oropharyngeal, hypo-and nasopharyngeal carcinomas, as well as non-melanoma skin cancer. Hepatitis B, Hepatitis C, and Kaposi's sarcomaassociated herpesviruses are involved in the development of various types of hepatocellular carcinomas [14]. The Epstein-Barr virus, in most cases, causes the development of the majority of lymphocyte-associated tumors, in particular, lymphoma [15]. In addition, the relationship between some viruses (retrovirus is activated by Kaposi's sarcoma-associated herpesvirus and the Epstein-Barr virus) and their ability to mutually activate and enhance each other's activity, thereby, promoting the development of tumors with subsequent carcinogenesis [16].

In the literary sources, there has been a longtime discussion about the importance of the influence of certain types of hormones on tumor genesis. Thus, among the main ones are androgen, estrogen, and progesterone - hormones that act through specific receptors and that play an important role in the growth and the development of several tumors, including breast, endometrial, and prostate carcinoma [8]. (Actis A.B., 2005) indicated a certain connection and a similarity of the histopathological types between the tumors of the salivary glands, the breast, and the prostate tumors. Thus, the structure of pleomorphic adenoma is very similar to a mucocellular tumor of the breast gland [17].

An analysis of the literary sources shows that the determinations of the immunohistochemical indices are performed by most scientists only for the tumor itself (pleomorphic adenoma of the salivary gland), without distributing them to the histological types and characterizing each of them separately $[6,7,8]$. Thus, according to O. Huskova's classification (2005), 4 types of pleomorphic adenomas of the salivary glands are distinguished according to the histological structure: mesenchymal, epithelial, combined, and myoepithelial [18]. According to the current study's research, the distributions among 28 patients with pleomorphic adenomas of the salivary glands by histological types were as follows: mesenchymal - 15 (53.57\%), epithelial - 3 (10.71\%), combined - 10 (35.71\%), myoepithelial - not observed.

The immunohistochemical studies conducted during this study determined the expressions of five major markers of pleomorphic adenoma by histological type: estrogen (ER), progesterone (PR), human papilloma virus type 16 (HPV), Epstein-Barr virus (EBV), and PLAG1. At the same time, the highest percentages of expression of the immunohistochemical markers were mostly characteristic of the mesenchymal and the combined (mesenchymal and epithelial) types. The following parameters were characteristics for the mesenchymal type of pleomorphic adenoma of the salivary gland: ER - 1 (6.66 \%), PR - 2 (13.33 \%), HPV type 16 - 11 (73.33 \%), EBV - 5 (33.33\%), and PLAG1 - 15 (100\%). For the combined type of pleomorphic adenoma of the salivary gland, the characteristics were the following parameters: ER - 1 (10 \%), PR - 1 (10 \%), HPV type $16-8$ (80 \%), EBV - 3 (30 \%), and PLAG1 - 10 (100 \%).

Hence, it can be stated that there is a certain dependence and dynamics of expression among the immunohistochemical indices for various histological types of pleomorphic adenoma of the salivary glands. While the PLAG1 marker was positive in almost all of the patients, the increased expression of HPV type 16 and EBV once again emphasized the viral tumor developmental pattern for the mesenchymal and the combined 
(mesenchymal and epithelial) histological types of pleomorphic adenomas. This was while the relatively low ER and PR parameters indicated a low endocrine dependence and an ability to further influence the tumor growth, but only in some cases.

Conclusions. The results of the conducted study of the own surgical material show that the structure of histological types of pleomorphic adenomas of the salivary glands is as follows: mesenchymal 15 (53.57 \%), epithelial-mesenchymal - 10 (35.47 \%), epithelial - 3 (10.71\%).

The mesenchymal and epithelial-mesenchymal types of histological structure of pleomorphic adenomas of the salivary glands are characterized by the similar immunohistochemical peculiarities (Plag1 - positive response in tumor cells of both histological types in $100 \%$ of cases; HPV $16-$ $73.33 \%$ and $80.0 \%$ respectively and EBV $-33.33 \%$ and $30.0 \%$ respectively).
The epithelial type of structure of the pleomorphic adenomas of the salivary glands is characterized by slightly different immunohistochemical pattern: Plag1 - positive response in tumor cells in $66.66 \%$ of cases; HPV 16 - also in $66.66 \%$ of cases.

The mesenchymal and epithelial-mesenchymal types of histological structure of pleomorphic adenomas of the salivary glands are characterized by more frequent invasion of HPV 16 and EBV.

The data obtained indicate that there are no statistically significant pairs of immunohistochemical indices among the 3 histological types of pleomorphic adenoma.

Funding. This research did not receive any specific grant from funding agencies in the public, commercial, or not-for-profit sectors.

Conflicts of Interest: authors have no conflict of interest to declare.

\section{(В. О. Маланчук ${ }^{1}$, І. С. Бродецький ${ }^{1}$, М. С. Кротевіч ${ }^{2}$}

Національний медичний університет імені О. О. Богомольця, м. Київ ${ }^{1}$

Національний інститут Раку, м. Київ ${ }^{2}$

\section{Застосування імуногістохімічних маркерів в діагностиці різних гістологічних типів плеоморфних аденом слинних залоз}

Резюме. Морфологічна верифікація пухлин, як метод діагностики, залишається вже тривалий час основним для встановлення заключного діагнозу. Точність встановлення діагнозу за різними даними складає від 80-85 \% залежно від виду пухлини (доброякісна чи злоякісна) та ступеня їі диференціювання. 3 упровадженням імуногістохімічних досліджень для заключної діагностики новоутворень, відсоток верифікації пухлин значно підвищився.

Мета дослідження - визначити особливості патогенезу різних гістологічних типів плеоморфних аденом слинних залоз шляхом застосування методів імуногістохімічної діагностики.

Матеріали і методи. Дослідження проведено на матеріалі ексцизійних біопсій доброякісних новоутворень слинних залоз (плеоморфних аденом) у 28 пацієнтів. Імуногістохімічне дослідження проводили 3 моноклональним антитілом миші проти людини Анті-Епштейна-Барр-вірус; 3 моноклональним антитілом кроля проти людини р16; 3 моноклональним антитілом кроля проти людини ЕР (естроген); з моноклональним антитілом миші проти людини ПР (прогестерон); моноклональним антитілом Плаг 1 (ген плеоморфної аденоми № 1).

Результати досліджень та їх обговорення. Результати проведених досліджень власного операційного матеріалу свідчать, що структура гістологічних типів плеоморфних аденом слинних залоз є наступною: мезенхімальний 15 (53,57 \%), мезенхімально-епітеліальний - 10 (35,47 \%), епітеліальний - 3 (10,71 \%). Для мезенхімального та мезенхімально-епітеліального типів гістологічної будови плеоморфних аденом слинних залоз характерні подібні імуногістохімічні особливості (Plag1 - pеакція позитивна в пухлинних клітинах обох гістологічних типах у 100 \% випадків; HPV 16 - відповідно 73,33 та 80,0 \% та EBV - відповідно у 33,33 і 30,0 \% випадків). Для епітеліального типу будови плеоморфних аденом слинних залоз характерна дещо інша імуногістохімічна картина: Plag1 - реакція в пухлинних клітинах позитивна у 66,66 \% випадків; HPV 16 - також у 66,66 \% випадків.

Висновки. Мезенхімальний та мезенхімально-епітеліальний типи гістологічної будови плеоморфних аденом слинних залоз характеризуються більш частим ураження вірусами папіломи людини 16 типу та Епштейна-Барр.

Ключові слова: пухлини слинних залоз; імуногістохімія; вірус папіломи людини; гістологічні типи плеоморфних аденом. 


\author{
(С. А. Маланчук ${ }^{1}$, И. С. Бродецкий ${ }^{1}$, М. С. Кротевич ${ }^{2}$ \\ Национальный медицинский университет имени А. А. Богомольца, г. Киев ${ }^{1}$ \\ Национальный институт Рака, г. Киев ${ }^{2}$
}

\title{
Применение иммуногистохимических маркеров в диагностике различных гистологических типов плеоморфных аденом слюнных желез
}

\begin{abstract}
Резюме. Морфологическая верификация опухолей, как метод диагностики, остается уже долгое время основным для установления окончательного диагноза. Точность постановки диагноза по разным данным составляет от 80-85 \% в зависимости от вида опухоли (доброкачественная или злокачественная) и степени ее дифференцировки. С внедрением иммуногистохимических исследований для заключительной диагностики новообразований, процент верификации опухолей значительно повысился.

Цель исследования - определить особенности патогенеза различных гистологических типов плеоморфных аденом слюнных желез путем применения методов иммуногистохимической диагностики.

Материалы и методы. Исследование проведено на материале эксцизионных биопсий доброкачественных новообразований слюнных желез (плеоморфных аденом) у 28 пациентов. Иммуногистохимическое исследование проводили с моноклональным мишиным антителом против человека Анти-Эпштейна-Барр- вирус; с моноклональным кроличьим антителом против человека р16; с моноклональным кроличьим антителом против человека ЭР (эстроген); с моноклональным мишиным антителом против человека ПР (прогестерон) клон; моноклональным антителом Плаг 1 (ген плеоморфной аденомы № 1).

Результаты исследований и их обсуждение. Результаты проведенных исследований собственного операционного материала свидетельствуют, что структура гистологических типов плеоморфных аденом слюнных желез является следующей: мезенхимальный 15 (53,57 \%), мезенхимальноэпителиальный - 10 (35,47 \%), эпителиальный - 3 (10 71\%). Мезенхимальный и мезенхимальноэпителиальный типы гистологического строения плеоморфных аденом слюнных желез имеют похожие иммуногистохимические особенности (Plag1 - реакция положительная в опухолевых клетках обеих гистологических типах в 100 \% случаев; HPV 16 - соответственно 73,33 и 80,0 \% и EBV - coответственно в 33,3 и 30,0 \% случаев). Для эпителиального типа строения плеоморфных аденом слюнных желез характерна несколько иная иммуногистохимическая картина: Plag1 - реакция в опухолевых клетках положительная в 66,66 \% случаев; HPV 16 - также в 66,66 \% случаев.

выводы. Мезенхимальный и мезенхимально-эпителиальный типы гистологического строения плеоморфных аденом слюнных желез характеризуются более частым поражением вирусами папилломы человека 16 типа и Эпштейна-Барр.
\end{abstract}

Ключевые слова: опухоли слюнных желез; иммуногистохимия; вирус папилломы человека; гистологические типы плеоморфных аденом.

\section{LIST OF LITERATURE}

1. Хірургічна стоматологія та щелепно-лицева хірургія. - в 2-х т. / під заг. ред. В. О. Маланчук. - К. : Логос, 2011. - Т. 1. - 627 с.

2. (2013). The involvement of growth differentiation factor 5 (GDF5) and aggrecan in the epithelialmesenchymal transition of salivary gland pleomorphic adenoma / A. S. Enescu, C. L. Mărgăritescu, M. M. Crăiţoiu [et al.] // Rom. J. Morphol. Embryol. 2013. - Vol. 54 (4). - P. 969-976.

3. Пачес А. И. Опухоли слюнных желез : ученик / А.И. Пачес, Т. Д. Таболиновская. - М. : Практическая медицина, 2009. - 470 с.

4. Functional histology of salivary gland pleomorphic adenoma: An appraisal / A. Triantafyllou, L. D. R. Thompson, K. O. Devaney [et al.] // Head Neck Pathol. - 2014. - Vol. 9 (3). - P. 387-404. DOI: 10.1007/ s12105-014-0581-1.
5. Prichard J. W. Overview of automated immunohistochemistry / J. W. Prichard // Arch. Pathol. Lab. Med. - 2014. - Vol. 138 (12). - P. 1578-1582. DOI: 10.5858/arpa.2014-0083-RA.

6. PLAG1 expression is maintained in recurrent pleomorphic adenoma / B. S. de Brito, N. G. Gaspar, E. S. Egal [et al.] // Virchows Arch. - 2016. - Vol. 469 (4). P. 477-481. DOI: 10.1007/s00428-016-1980-3.

7. Human papillomavirus and salivary gland neoplasia: a p16INK4 immunohistochemical and in situ hybridization study / M. S. Miah, S. Majumdar, S. White [et al.] // J. Laryngol. Otol. - 2015. - Vol. 129 (10). -

P. 1000-1003. DOI: $10.1017 /$ S0022215115001851.

8. Sex hormone receptors in benign and malignant salivary gland tumors: Prognostic and predictive role / G. Aquino, F. Collina, R. Sabatino [et al.] // Int. J. Mol. Sci. 2018. - Vol. 19 (2). pii: E399. DOI: 10.3390/ijms19020399. 
9. Ryabko B. A new test for randomness and its application to some cryptographic problems / B. Ryabko, V. Stognienko, Yu. Shokin // Journal of Statistical Planning and Inference. - 2004. - Vol. 123 (2). - P. 365-376. - Access mode : https://doi.org/10.1016/ S0378-3758(03)00149-6.

10. Mori H. Methods of Immunohistochemistry and Immunofluorescence: Converting invisible to visible / H. Mori, R. D. Cardiff // Methods Mol. Biol. - 2016. Vol. 1458. - P. 1-12. DOI: 10.1007/978-1-4939-3801-8_1.

11. Lin F. Standardization of diagnostic immunohistochemistry: Literature review and Geisinger experience / F. Lin, Z. Chen // Arch. Pathol. Lab. Med. - 2014. - Vol. 138 (12). - P. 1564-1577. DOI: 10.5858/arpa.2014-0074-RA.

12. Weinreb I. Translocation-associated salivary gland tumors: a review and update / I. Weinreb // Adv. Anat. Pathol. - 2013. - Vol. 20 (6). - P. 367-377. DOI: 10.1097/ PAP.0b013e3182a92cc3.

13. Prevalence of human papillomavirus and EpsteinBarr virus in salivary gland diseases / F. C. Lin, P. L. Chen, T. Y. Tsao [et al.] // J. Int. Med. Res. - 2014. Vol.42(5).-P.1093-1101.DOI:14.1177/0300060514543041.

\section{REFERENCES}

1. Malanchuk, V.O. (2011). Khirurhichna stomatolohiia ta shchelepno-lytseva khirurhiia [Surgical dentistry and maxillofacial surgery]. Kyiv: Lohos [in Ukrainian].

2. Enescu, A.S., Mărgăritescu, C.L., Crăiţoiu, M.M., Enescu, A., Crăiţoiu, Ş. (2013). The involvement of growth differentiation factor 5 (GDF5) and aggrecan in the epithelial-mesenchymal transition of salivary gland pleomorphic adenoma. Rom. J. Morphol. Embryol., 54 (4), 969-976.

3. Paches, A.I., \& Tabolinovskaya, T.D. (2007). Opukholy slyunnykh zhelez [Tumors of the salivary glands]. Moscow: Prakticheskaya meditsina [in Russian].

4. Triantafyllou, A., Thompson, L.D.R., \& Devaney, K.O. (2014). Functional histology of salivary gland pleomorphic adenoma: An appraisal. Head Neck Pathol., 9 (3), 387-404. DOI: 10.1007/s12105-014-0581-1.

5. Prichard, J.W. (2014). Overview of automated immunohistochemistry. Arch. Pathol. Lab. Med., 138 (12), 1578-1582. DOI: 10.5858/arpa.2014-0083-RA.

6. de Brito, B.S., Gaspar, N.G., \& Egal, E.S. (2016). PLAG1 expression is maintained in recurrent pleomorphic adenoma. Virchows Arch., 469 (4), 477-481. DOI: 10.1007/ s00428-016-1980-3.

7. Miah, M.S., Majumdar, S., \& White, S. (2015). Human papillomavirus and salivary gland neoplasia: a p16INK4 immunohistochemical and in situ hybridization study. J. Laryngol. Otol., 129 (10), 1000-1003. DOI: 10.1017/ S0022215115001851.

8. Aquino, G., Collina, F., \& Sabatino, R. (2018). Sex hormone receptors in benign and malignant salivary gland tumors: Prognostic and predictive role. Int. J. Mol. Sci., 19 (2), pii: E399. doi: 10.3390/ijms19020399.

9. Ryabko, B., Stognienko, V., \& Shokin, Yu. (2004). A new test for randomness and its application to some cryptographic problems. Journal of Statistical Planning and Inference, 123 (2), 365-376. Retrieved from: https:// doi.org/10.1016/S0378-3758(03)00149-6.

10. Mori, H., \& Cardiff, R.D. (2016). Methods of
14. Cancer progression goes viral: The role of oncoviruses in aggressiveness of malignancies / B. G. Müller-Coan, B. F. R. Caetano, J. S. Pagano, D. Elgui de Oliveira // Trends Cancer. - 2018. - Vol. 4 (7). - P. 485-498. DOI: 10.1016/j. trecan.2018.04.006.

15. Role of Epstein-Barr virus and cytomegalovirus in the etiology of benign parotid tumors / C. J. Laane, A. H. Murr, A. N. Mhatre [et al.] // Head Neck. - 2002. Vol. 24 (5). - P. 443-450. DOI: 10.1002/hed.10065.

16. Chen J. Transactivation of human endogenous retroviruses by tumor viruses and their functions in virus-associated malignancies / J. Chen, M. Foroozesh, Z. Qin // Oncogenesis. - 2019. - Vol. 8 (1). - P. 6. DOI: $10.1038 / \mathrm{s} 41389-018-0114-y$.

17. Actis A. B. A hypothesis to relate salivary tumors with mammary and prostate neoplasias / A. B. Actis // Bioinformation. - 2005. - Vol. 1 (1). - P. 12-13. PMID: 17597843.

18. Гуськова О. Н. Морфология плеоморфной аденомы слюнных желез : автореф. дисс. на соискание науч. степени канд. мед. наук : 14.00.15. СанктПетербург, 2005. 16 с.

immunohistochemistry and immunofluorescence: Converting invisible to visible. Methods Mol. Biol., 1458, 1-12. DOI: 10.1007/978-1-4939-3801-8_1.

11. Lin, F., \& Chen, Z. (2014). Standardization of diagnostic immunohistochemistry: Literature review and Geisinger experience. Arch. Pathol. Lab. Med., 138 (12), 1564-1577. DOI: 10.5858/arpa.2014-0074-RA.

12. Weinreb, I. (2013). Translocation-associated salivary gland tumors: a review and update. Adv. Anat. Pathol., 20 (6), 367-77. DOI: 10.1097/PAP.0b013e3182a92cc3.

13. Lin, F.C., Chen, P.L., \& Tsao, T.Y. (2014). Prevalence of human papillomavirus and Epstein-Barr virus in salivary gland diseases. J. Int. Med. Res., 42 (5), 109310101. DOI: $14.1177 / 0300060514543041$.

14. Müller-Coan, B.G., Caetano, B.F.R., Pagano, J.S., \& Elgui de Oliveira D. (2018). Cancer progression goes viral: The role of oncoviruses in aggressiveness of malignancies. Trends Cancer, 4 (7), 485-498. DOI: 10.1016/j.trecan.2018.04.006.

15. Laane, C.J., Murr, A.H., Mhatre, A.N., Jones, K.D., \& Lalwani, A.K. (2002). Role of Epstein-Barr virus and cytomegalovirus in the etiology of benign parotid tumors. Head Neck, 24 (5), 443-450. DOI: 10.1002/ hed.10065.

16. Chen, J., Foroozesh, M., \& Qin, Z. (2019). Transactivation of human endogenous retroviruses by tumor viruses and their functions in virus-associated malignancies. Oncogenesis, 8 (1), 6. DOI: 10.1038/s41389018-0114-y.

17. Actis, A.B. (2005). A hypothesis to relate salivary tumors with mammary and prostate neoplasias. Bioinformation, 1(1), 12-13. PMID: 17597843.

18. Huskova, O.N. (2005). Morfologiya pleomorfnoy adenoma slyunnykh zhelez [The morphology of the pleomorphic adenoma of salivary glands]. Extended abstract Candidate's thesis. St. Petersburg. Retrieved from: https://www.dissercat.com/content/morfologiyapleomorfnoi-adenomy slyunnykh-zhelez. 